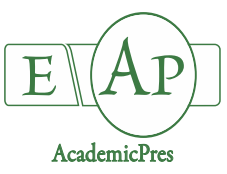

Girotto L et al. (2021)

Notulae Botanicae Horti Agrobotanici Cluj-Napoca

Volume 49, Issue 3, Article number 12440

DOI: $10.15835 /$ nbha 49312440

Research Article

\title{
Phytotoxicity and allelopathic potential of extracts from rhizomes and leaves of Arundo donax, an invasive grass in neotropical savannas
}

\author{
Lucas GIROTTO ${ }^{1}$, Augusto C. FRANCO${ }^{1}$, Cecília V. NUNEZ ${ }^{2}$, \\ Sarah C. C. OLIVEIRA ${ }^{1}$, Maria C. SCHEFFER de SOUZA², \\ Maria T. FACHIN-ESPINAR ${ }^{2}$, Cristiane S. FERREIRA ${ }^{1 *}$ \\ IUniversity of Brasilia, Department of Botany,Brasilia,DF 70910-900,Brazil; lucasgirotto1994@gmail.com; acfranco@unb.br; \\ sarahc.caldas@gmail.com; cferreiraunb@gmail.com (*corresponding author) \\ ${ }^{2}$ National Institute of Amazonian Research (INPA), Laboratory of Bioprospecting and Biotechnology, Manaus, AM 69067-375, \\ Brazil;cecilia@inpa.gov.br; mcarol.biotec@gmail.com;matefa5@hotmail.com
}

\begin{abstract}
The perennial rhizomatous grass Arundo donax L. (Poaceae), the giant reed, is an exotic invasive species in several countries of Europe that is rapidly spreading in the savannas of Central Brazil, locally known as Cerrado. Allelopathy could facilitate the successful invasion of this species by hampering or suppressing the regeneration of the native vegetation. However, information on the phytotoxicity of $A$. donax extracts is limited. We investigated the allelopathic potential of $A$. donax leaf and rhizome extracts, screened them for phytochemicals by thin-layer chromatography (TLC) and nuclear magnetic resonance ( $\left.{ }^{1} \mathrm{H}-\mathrm{NMR}\right)$, and tested the extracts for antioxidant activity, antimicrobial activity, and cytotoxicity against Artemia salina. Aqueous and methanolic extracts were initially tested in germination and seedling growth bioassays using Lactuca sativa L. (Asteraceae). The aqueous extracts were then tested on five Cerrado tree species and on Megathyrsus maximus, an invasive, alien grass in the Cerrado. Extracts negatively affected germination and seedling growth of the target species. Leaf extracts were more inhibitory. Extracts did not show antioxidant and cytotoxic activity and had very low antimicrobial activity. Flavonoids, and other phenolics were detected mostly in leaves. Terpenes, which were also present in the leaves, were the main secondary metabolites in rhizomes. Alkaloids were detected by TLC in leaf methanolic extracts. However, ${ }^{1} \mathrm{H}-\mathrm{NMR}$ revealed the presence of indole alkaloids in methanolic extracts from rhizomes and leaves. We confirmed the allelopathic potential of this species and caution against weed control methods relying on cutting the plant back to soil level for favouring release of allelochemicals.
\end{abstract}

Keywords: biological invasion; Cerrado; giant reed; phytochemistry

\section{Introduction}

Arundo donax L. (Poaceae), known as giant reed, is a perennial rhizomatous grass, native to Asia and the Mediterranean (Mariani et al., 2010) that is an exotic invasive species in several countries of Europe and the Americas (Boose and Holt, 1999; Favaretto et al., 2018). Although it thrives in the most different types of 
soil and environmental conditions, $A$. donax is considered a hydrophyte and has its growth favoured in wetlands, where it can quickly expand and form large stands, especially along river channels (Bell, 1997; Corno et al., 2014). The plant spreads vegetatively from the stem and the rhizome (Mariani et al., 2010). Its establishment may result in losses of composition, structure, and functioning of native plant and animal communities and of ecosystem processes, which can often not be recovered (Bell, 1997; Coffman et al., 2010; Maceda-Veiga et al., 2016).

This is especially critical in the Cerrado of Central Brazil, a complex of seasonal savannas and a hotspot of highly threatened biodiversity (Gomes et al., 2020). The propagation of $A$. donaxin the Cerrado is favoured by the characteristics of its phytophysiognomies, with the dominance of open, herbaceous vegetation with scattered trees and shrubs, which is undergoing fast rates of degradation by human activities and increasingly frequent fires (Myers et al., 2000; Gomes et al., 2020). Colonization by this species increases fuel loads as well as fire frequency and intensity. In addition to increasing the risk of fires, $A$. donax has a rapid recovery after fire, therefore, imposing a strong negative effect on the regeneration of the native vegetation (Coffman et al., 2010). Arundo donax has been rapidly spreading throughout anthropic areas in Central Brazil, and, more recently, invaded wetlands and preserved vegetation areas (Simões et al., 2013; IABIN, 2019).

Among the mechanisms responsible for the success in the invasion of some exotic plant species is the release of chemical compounds, products from secondary metabolism, which have harmful or positive effects on community members living in the environment, a process known as Allelopathy (Fujii, 2003; Favaretto et al., 2018; Możdżeń et al., 2020). Understanding whether the interaction of $A$. donax with other plant species involves allelochemicals is important to elucidate the mechanisms that favour the invasion of this species into a new area (Hierro and Callaway, 2003).

Indole alkaloids and other nitrogenous aromatic substances were isolated from the leaves (Hong et al., 2010), rhizomes, and roots (Al-Snafi, 2015) of $A$. donax. However, information on the allelopathic potential of $A$. donax is limited. The crude aqueous extract of $A$. donax leaves inhibited the germination and growth of lentil seedlings (Lens culinaris Medik) (Abu-Romman and Ammari, 2015). The methanolic extract of $A$. donax leaves had an inhibitory effect on the proliferation of Microcystis aeruginosa, cyanobacteria responsible for water contamination in reservoirs (Hong et al., 2010). As far as we know, there are no phytotoxic studies performed with extracts from $A$. donax rhizomes. The allelopathic potential of this structure was shown for other grasses with invasive behaviour, such as Cynodon dactylon, whose aqueous rhizome extract inhibited almost entirely the germination and growth of several other plant species (Mahmoodzadeh and Mahmoodzadeh, 2014).

In the present study, we evaluated the phytotoxic potential of extracts from leaves and rhizomes of $A$. donax. Because this species forms dense stands and is invasive of wetlands in the Cerrado, we expected that aqueous extracts of leaves and rhizomes would affect the germination and growth of other plants, show antimicrobial activity, and affect water quality. We also screened the crude extracts for the main secondary metabolites.

\section{Materials and Methods}

\section{Plant material}

Leaves and rhizomes of $A$. donax were collected from ten adult plants, with no inflorescences, in an area

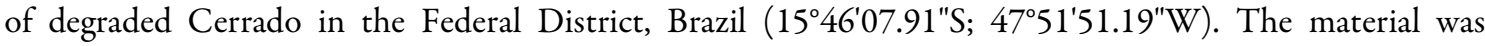
immediately transported to the University of Brasilia, washed in running water, and dried in a drying oven at $60^{\circ} \mathrm{C}$ for 72 hours. 


\section{Plant extracts}

Aqueous extracts: crude $10 \%(\mathrm{w} / \mathrm{v})$ water extracts were obtained from leaves and rhizomes. The leaves were shredded in a cutting mill (Tecnal R-TE-650/1) and placed in an ultrasonic bath for 45 minutes. The fibrous rhizome was cut into pieces $\left(\leq 1 \mathrm{~cm}^{3}\right)$, placed in suspension in deionized water for 48 hours, and extracted for 4 hours in an ultrasonic bath. Both extracts were filtered twice on filter paper with the aid of a vacuum pump and lyophilized.

Methanolic extracts: the procedure was the same described for the aqueous extracts, replacing the water with $99.9 \%$ methanol. After obtaining the extracts, the solvent was evaporated in a rotary evaporator until the complete drying of the material. Dry fractions were weighed, dissolved in distilled water, and added dimethylsulfoxide (DMSO) $0.05 \%$ (v/v).

Dilutions of 10, 5, 2.5, and $1.25 \%$ were prepared from the aqueous and methanolic crude extracts.

\section{Germination and seedling growth bioassay}

The allelopathic potential of aqueous and methanolic extracts from leaves and rhizomes of $A$. donaxwas initially tested with the model species Lactuca sativa L. (Asteraceae). The experimental design was completely randomized with five replications of ten seeds each that were assembled in Petri dishes with filter paper and 1.5 $\mathrm{mL}$ of each extract concentration (10, 5, 2.5, and 1.25\%). Controls received distilled water. The petri dishes were kept in a germination chamber at $25^{\circ} \mathrm{C}$ with $12 \mathrm{~h}$ photoperiod for seven days. After this period, germination was assessed and root and shoot length measured.

The phytotoxicity (inhibition of germination, root and shoot elongation) for species that occur in the Cerrado was then tested with aqueous extract from leaves and rhizomes of $A$. donax, to simulate what occurs in the field. The phytotoxicity of the aqueous extracts was tested at different concentrations $(10,5,2.5$, and $1.25 \%$ ) in bioassays with seedlings of six species: Megathyrsus maximus (Jacq.) B.K.Simon and S.W.L.Jacobs (Poaceae), an invasive African grass co-occurring with $A$. donax in degraded Cerrado areas and with similar growth characteristics (Horowitz et al., 2013) (Figure S1, Supplementary material); Handroanthus impetiginosus (Mart. ex DC.) Mattos (Bignoniaceae), Eriotheca pubescens (Mart. and Zucc.) Schott and Endl. (Malvaceae), Pseudobombax tomentosum (Mart. and Zucc.) A. Robiyns (Malvaceae), Guazuma ulmifolia Lam. (Sterculiaceae), and Parkia platycephala Benth. (Fabaceae), native tree species of the biome. These trees are commonly found in urban fragments of Cerrado vegetation, where the invasion of $A$. donax is favoured. The bioassays were assembled in Petri dishes $(60 \times 15 \mathrm{~mm})$ with filter paper and $1.5 \mathrm{~mL}$ of each extract concentration.

The experimental design was completely randomized with four replications of ten seeds each. The plates were kept in a germination chamber at $25^{\circ} \mathrm{C}$ with $12 \mathrm{~h}$ photoperiod for seven days for M. maximus and fourteen days for the remaining species. After this period, germination was scored, seedlings were photographed, and the shoot and radicle length measured with the program Image ${ }^{\circ}$. Radicle length was scored as zero when the seed germinated (i. e. the radicle emerged from the seed coat) but the radicle failed to elongate.

\section{Phytochemical screening}

Phytochemical screening was performed for the main secondary metabolites from crude aqueous and methanolic extracts of $A$. donax leaves or rhizomes. Thin-layer chromatography, a classical qualitative method, was used to detect tannins and saponins (Pascual et al., 2002), alkaloids (Peres et al., 2012), flavonoids (Calina et al., 2013), anthocyanins, triterpenoids, and steroids (Jork et al., 1990).

\section{Antioxidant activity}

Samples of $5 \mathrm{mg}$ of dried extracts of leaves and rhizomes were weighed and diluted in $10 \mathrm{~mL}$ of methanol. To test for antioxidant activity, two methods were used simultaneously, DPPH and $\mathrm{Fe}^{3+}$-phenanthroline, both in triplicate (Martins et al., 2014), with ascorbic acid as standard curve, and the results were expressed as ascorbic acid equivalent. 
Nuclear magnetic resonance

${ }^{1} \mathrm{H}$ nuclear magnetic resonance (NMR) was used to identify functional groups and chemical classes present in aqueous and methanolic extracts of leaves and rhizomes. $25 \mathrm{mg}$ of dried samples of aqueous extracts were diluted in deuterated water $\left(\mathrm{D}_{2} \mathrm{O}\right)$, and $25 \mathrm{mg}$ of dried samples of methanolic extracts were diluted in dimethylsulfoxide deuterated $\left(\mathrm{DMSO}-d_{6}\right)$. The NMR analyses were performed on a Bruker Fourier 300, operating at $300 \mathrm{MHz}$ for the ${ }^{1} \mathrm{H}$ nucleus.

\section{Toxicity test against Artemia salina}

The cytotoxicity of the extracts was tested in bioassay against larvae of Artemia salina (Meyer et al., 1982). Eggs were placed in a solution of salinized water for 48 hours for the hatching of the crustaceans. Aqueous extracts were tested at concentrations of $1000,500,250,125,60$, and $30 \mu \mathrm{g} \cdot \mathrm{mL}^{-1}$ of salinized water. The lethality of the extracts was evaluated after incubation periods of 24 hours.

\section{Antimicrobial activity}

The microorganisms were donated by the Laboratory of Reference for Microorganisms of the National Institute of Quality Control in Health, from the Oswaldo Cruz Foundation: Acinetobacter baumannii ATCC 19606; Aeromonas hydrophila IOC/FDA 110-36; Candida albicans ATCC 10231, CBS 6431; CBS 604; Citrobacter freundii ATCC 8090; Edwardsiella tarda ATCC 15947; Enterobacter cloacae ATCC 13047; Eschericia coli ATCC 11775; Klebsiella pneumoniae ATCC 13883; Morganella morganii ATCC 00082; Pseudomonas aeruginosa ATCC 10145; Pseudomonas fluorescens ATCC 13525 (NCTC 10038); Salmonella enterica ATCC 13076; Serratia marcescens ATCC 13880; Staphylococcus aureus ATCC 12600. The bacterial colonies were inoculated from pure 24-hour cultures in Müeller Hinton broth and homogenized. The turbidity of the inoculum was adjusted to match a $0.5 \mathrm{MacF}$ arland standard, corresponding to a suspension containing 1-2 x $10^{8}$ colony-forming units $\left(\mathrm{CFU} \cdot \mathrm{mL}^{-1}\right)$. The test microorganisms were diluted (1:20), and 10 $\mathrm{mL}$ of each were inoculated in 96 well plates. The antimicrobial activity was evaluated with different fractions of the extracts $\left(1000,500,250,125,62.25,31.12\right.$, and $\left.15.5 \mu \mathrm{g} \cdot \mathrm{mL}^{-1}\right)$ and the determination of microbial growth was performed by spectrophotometer at $625 \mathrm{~nm}$. The positive control was oxytetracycline $125 \mu \mathrm{g} \cdot \mathrm{mL}^{-1}$ and the negative control was the culture medium itself.

\section{Statistical analyses}

ANOVA followed by Tukey's HSD test for pairwise comparisons was used for the statistical analyses after checking for normality with the Shapiro-Wilk test and homogeneity of variances with the Levene test. The Kruskal-Wallis test followed by Dunn's tests was applied, when the data did not follow a normal distribution or were heteroscedastic. Differences were considered to be significant at $\mathrm{P}<0.05$. The program RStudio 1.3 was used for the statistical analysis.

\section{Results}

Aqueous and methanolic extracts from leaves or rhizomes caused a significant reduction in L. sativa seed germination at higher concentrations. Both extracts inhibited seedling growth in a dose-dependent manner (Table 1). 
Table 1. The effect of different concentrations of aqueous and methanolic extracts (\%) from leaves and rhizomes of Arundo donax on percentage seed germination, root and shoot growth of seedlings of Lactuca sativa L. (Asteraceae)

\begin{tabular}{|l|c|c|c|c|c|c|}
\hline \multirow{2}{*}{$\begin{array}{c}\text { Concentrations } \\
\text { of extracts }\end{array}$} & \multicolumn{2}{|c|}{ Germination $(\%)$} & \multicolumn{2}{c|}{ Shoot length $(\mathrm{cm})$} & \multicolumn{2}{c|}{ Root length (cm) } \\
\cline { 2 - 7 } & Aqueous & Methanolic & Aqueous & Methanolic & Aqueous & Methanolic \\
\hline Leaf extracts & $94.5 \pm 2.7 \mathrm{a}$ & $97.5 \pm 2.3 \mathrm{a}$ & $1.26 \pm 0.29 \mathrm{a}$ & $1.30 \pm 0.06 \mathrm{a}$ & $3.68 \pm 0.37 \mathrm{a}$ & $4.38 \pm 0.27 \mathrm{a}$ \\
\hline Control & $92.3 \pm 6.9 \mathrm{a}$ & $82.5 \pm 4.8 \mathrm{ab}$ & $1.16 \pm 0.03 \mathrm{a}$ & $1.33 \pm 0.08 \mathrm{a}$ & $2.87 \pm 0.37 \mathrm{a}$ & $3.99 \pm 0.20 \mathrm{a}$ \\
\hline $1.25 \%$ & $95.0 \pm 2.6 \mathrm{a}$ & $60.0 \pm 7.8 \mathrm{~b}$ & $0.86 \pm 0.06 \mathrm{ab}$ & $1.09 \pm 0.11 \mathrm{ab}$ & $1.58 \pm 0.08 \mathrm{~b}$ & $1.73 \pm 0.13 \mathrm{~b}$ \\
\hline $2.50 \%$ & $75.3 \pm 1.5 \mathrm{~b}$ & $22.5 \pm 4.6 \mathrm{c}$ & $0.61 \pm 0.10 \mathrm{bc}$ & $0.76 \pm 0.14 \mathrm{~b}$ & $0.91 \pm 0.18 \mathrm{bc}$ & $0.75 \pm 0.12 \mathrm{c}$ \\
\hline $5 \%$ & $39.0 \pm 3.0 \mathrm{c}$ & $10.0 \pm 6.5 \mathrm{c}$ & $0.00 \pm 0.00 \mathrm{c}$ & $0.00 \pm 0.00 \mathrm{c}$ & $0.00 \pm 0.00 \mathrm{c}$ & $0.00 \pm 0.00 \mathrm{c}$ \\
\hline $10 \%$ & $95.5 \pm 2.3 \mathrm{a}$ & $97.5 \pm 2.3 \mathrm{a}$ & $1.25 \pm 0.29 \mathrm{a}$ & $1.30 \pm 0.06 \mathrm{a}$ & $3.68 \pm 0.37 \mathrm{a}$ & $4.38 \pm 0.27 \mathrm{a}$ \\
\hline Rhizome extracts & $95.0 \pm 4.6 \mathrm{a}$ & $85.0 \pm 5.6 \mathrm{ab}$ & $1.23 \pm 0.05 \mathrm{a}$ & $1.09 \pm 0.13 \mathrm{ab}$ & $3.04 \pm 0.21 \mathrm{ab}$ & $1.73 \pm 0.16 \mathrm{~b}$ \\
\hline Control & $95.6 \pm 5.1 \mathrm{a}$ & $80.0 \pm 1.4 \mathrm{~b}$ & $1.16 \pm 0.06 \mathrm{a}$ & $1.00 \pm 0.03 \mathrm{~b}$ & $2.98 \pm 0.18 \mathrm{~b}$ & $1.02 \pm 0.03 \mathrm{bc}$ \\
\hline $1.25 \%$ & $92.2 \pm 4.4 \mathrm{a}$ & $65.0 \pm 9.1 \mathrm{~b}$ & $0.73 \pm 0.15 \mathrm{~b}$ & $0.27 \pm 0.01 \mathrm{c}$ & $1.21 \pm 0.36 \mathrm{c}$ & $0.32 \pm 0.01 \mathrm{~cd}$ \\
\hline $2.50 \%$ & $43.4 \pm 2.0 \mathrm{~b}$ & $12.5 \pm 6.9 \mathrm{c}$ & $0.00 \pm 0.00 \mathrm{~b}$ & $0.00 \pm 0.00 \mathrm{c}$ & $0.00 \pm 0.00 \mathrm{~d}$ & $0.00 \pm 0.00 \mathrm{~d}$ \\
\hline $5 \%$ &
\end{tabular}

Controls received distilled water. Different letters within a single column of leaf or rhizome extracts denote significant differences at $\mathrm{P}<0.05$ between concentration levels. Data expressed as mean \pm standard error.

Similarly, at the highest concentrations, aqueous extracts from leaves of $A$. donax strongly reduced seed germination and seedling growth on the other tested species when compared to untreated controls (Table 2, Figure 1 and Table S1, Supplementary material).

Table 2. Percentage seed germination of five Cerrado tree species and one invasive African grass (Megathyrsus maximus) treated with different concentrations of Arundo donax leaf and rhizome aqueous extracts, plus the control

\begin{tabular}{|c|c|c|c|c|c|c|}
\hline $\begin{array}{c}\text { Concentra- } \\
\text { tions of } \\
\text { extracts }\end{array}$ & $\begin{array}{c}\text { Handroanthus } \\
\text { impetiginosus }\end{array}$ & $\begin{array}{c}\text { Megathyrsus } \\
\text { maximus }\end{array}$ & $\begin{array}{c}\text { Eriotheca } \\
\text { pubescens }\end{array}$ & $\begin{array}{c}\text { Guazuma } \\
\text { ulmifolia }\end{array}$ & $\begin{array}{c}\text { Parkia } \\
\text { platycephala }\end{array}$ & $\begin{array}{c}\text { Pseudobombax } \\
\text { tomentosum }\end{array}$ \\
\hline & \multicolumn{7}{|c|}{ Seeds treated with leaf extracts } \\
\hline Control & $90.0 \pm 5.0 \mathrm{a}$ & $45.0 \pm 7.4 \mathrm{a}$ & $77.5 \pm 5.4 \mathrm{a}$ & $47.5 \pm 3.8 \mathrm{a}$ & $45.0 \pm 2.3 \mathrm{a}$ & $32.5 \pm 1.5 \mathrm{a}$ \\
\hline $1.25 \%$ & $57.5 \pm 13.4 \mathrm{ab}$ & $23.0 \pm 2.8 \mathrm{ab}$ & $60.0 \pm 11.1 \mathrm{ab}$ & $35.0 \pm 3.5 \mathrm{ab}$ & $35.0 \pm 6.3 \mathrm{ab}$ & $30.0 \pm 0.9 \mathrm{a}$ \\
\hline $2.50 \%$ & $47.5 \pm 9.2 \mathrm{bc}$ & $17.5 \pm 5.5 \mathrm{~b}$ & $27.5 \pm 8.4 \mathrm{bc}$ & $25.0 \pm 2.4 \mathrm{bc}$ & $25.0 \pm 2.3 \mathrm{bc}$ & $20.0 \pm 2.7 \mathrm{bc}$ \\
\hline $5 \%$ & $40.0 \pm 1.4 \mathrm{bc}$ & $7.5 \pm 0.8 \mathrm{~b}$ & $20.0 \pm 3.6 \mathrm{c}$ & $15.0 \pm 3.5 \mathrm{~cd}$ & $15.0 \pm 1.5 \mathrm{~cd}$ & $20.0 \pm 3.0 \mathrm{bc}$ \\
\hline $10 \%$ & $22.5 \pm 3.3 \mathrm{c}$ & $2.5 \pm 0.2 \mathrm{~b}$ & $20.0 \pm 0.4 \mathrm{c}$ & $10.0 \pm 1.7 \mathrm{~d}$ & $10.0 \pm 1.1 \mathrm{~d}$ & $10.0 \pm 2.7 \mathrm{c}$ \\
\hline \multicolumn{7}{|c|}{ Seeds treated with rhizome extracts } \\
\hline Control & $90.0 \pm 5.0 \mathrm{a}$ & $45.0 \pm 7.4 \mathrm{a}$ & $77.5 \pm 5.4 \mathrm{a}$ & $47.5 \pm 3.8 \mathrm{a}$ & $45.0 \pm 4.6 \mathrm{a}$ & $32.5 \pm 1.5 \mathrm{ab}$ \\
\hline $1.25 \%$ & $55.0 \pm 14.7 \mathrm{a}$ & $35.0 \pm 6.1 \mathrm{ab}$ & $77.5 \pm 5.5 \mathrm{a}$ & $32.5 \pm 3.6 \mathrm{~b}$ & $32.5 \pm 3.9 \mathrm{~b}$ & $37.5 \pm 1.9 \mathrm{a}$ \\
\hline $2.50 \%$ & $57.5 \pm 14.5 \mathrm{a}$ & $27.5 \pm 0.7 \mathrm{ab}$ & $77.5 \pm 5.9 \mathrm{a}$ & $42.5 \pm 5.2 \mathrm{ab}$ & $42.5 \pm 4.7 \mathrm{ab}$ & $37.5 \pm 1.3 \mathrm{a}$ \\
\hline $5 \%$ & $72.5 \pm 10.6 \mathrm{a}$ & $20.0 \pm 0.2 \mathrm{~b}$ & $82.5 \pm 7.2 \mathrm{a}$ & $35.0 \pm 0.4 \mathrm{ab}$ & $35.0 \pm 6.2 \mathrm{ab}$ & $27.5 \pm 0.6 \mathrm{~b}$ \\
\hline $10 \%$ & $55.0 \pm 11.5 \mathrm{a}$ & $37.5 \pm 6.4 \mathrm{ab}$ & $97.5 \pm 1.8 \mathrm{a}$ & $15.0 \pm 4.2 \mathrm{c}$ & $15.0 \pm 2.4 \mathrm{c}$ & $10.0 \pm 3.0 \mathrm{c}$ \\
\hline
\end{tabular}

Different letters within a single column of leaf or rhizome extracts denote significant differences at $\mathrm{p}<0.05$ between concentration levels. Data expressed as mean \pm standard error.

Aqueous rhizome extracts had detrimental effects in germination of G. ulmifolia, M. maximus, $P$. platycephala and $P$. tomentosum, in the root and shoot growth of seedlings of $E$. pubescens and $P$. tomentosum, and in the root growth of $P$. platycephala (Table 2, Figure 2). 


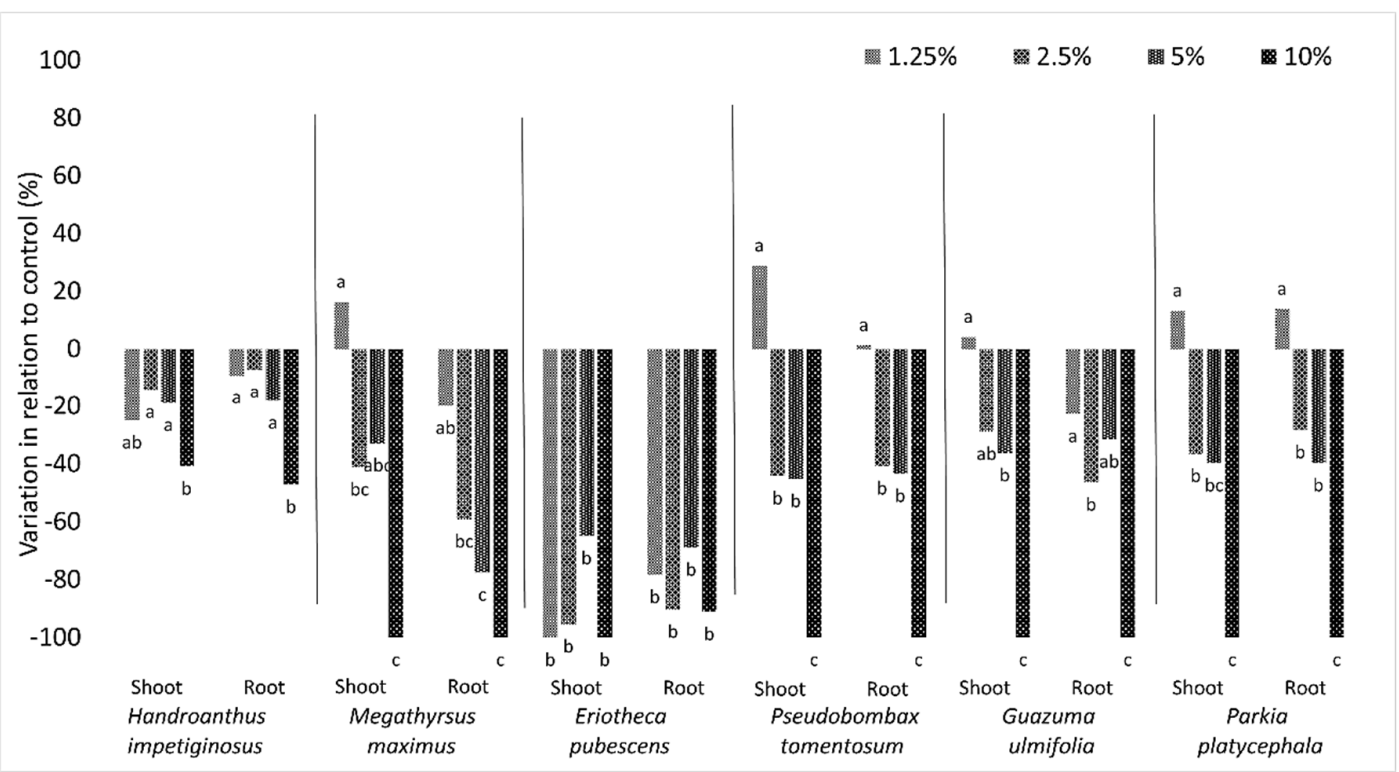

Figure 1. Effects of different concentrations (\%) of aqueous leaf extracts from Arundo donax on shoot and root length of seedlings of the invasive African grass Megathyrsus maximus and five native Cerrado tree species Values are expressed as a percentage difference from control. Different letters denote significant differences at $\mathrm{p}<0.05$ between concentration levels. Concentration levels with letter "a" do not differ from controls.

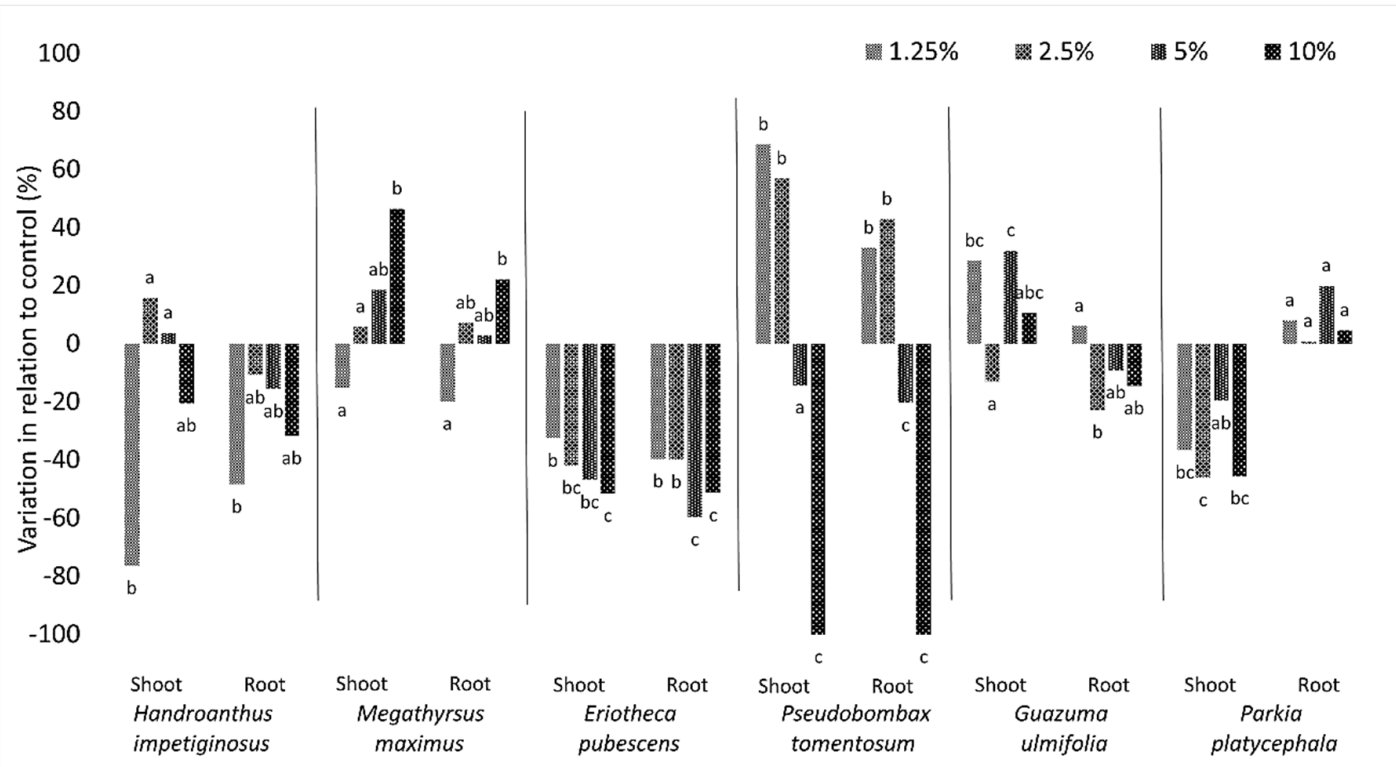

Figure 2. Effects of different concentrations (\%) of aqueous rhizome extracts from Arundo donax on shoot and root length of seedlings of the invasive grass Megathyrsus maximus and five native Cerrado tree species Values are expressed as a percentage difference from control. Different letters denote significant differences at $\mathrm{p}<0.05$ between concentration levels. Concentration levels with letter "a" do not differ from controls.

Thin-layer chromatography analysis (Table 3) revealed the presence of terpenes in the aqueous and methanolic extracts of leaves and rhizomes and flavonoids in the leaf aqueous extracts. Phenolic compounds, alkaloids, and flavonoids were detected in the leaf methanolic extracts of $A$. donax. 
Table 3. Main chemical classes of compounds detected by thin-layer chromatography (TLC) analysis in aqueous and methanolic extracts of leaves and rhizomes of Arundo donax

\begin{tabular}{|l|c|c|c|c|c|}
\hline \multicolumn{1}{|c|}{ Extract } & $\begin{array}{c}\text { Dragendorff } \\
\text { (alkaloids) }\end{array}$ & $\begin{array}{c}\text { NP-PEG } \\
\text { (flavonoids) }\end{array}$ & $\begin{array}{c}\text { Presence of persistent } \\
\text { foam (saponins) }\end{array}$ & $\begin{array}{c}\text { Ferric chloride } \\
\text { (phenolics) }\end{array}$ & $\begin{array}{c}\text { Anisaldehyde } \\
\text { (Terpenes) }\end{array}$ \\
\hline Aqueous & & & - & - & + \\
\hline Rhizome & - & - & - & - & + \\
\hline Leaves & - & + & - & - & + \\
\hline Methanolic & & - & - & + & + \\
\hline Rhizome & - & + & - & - & + \\
\hline Leaves & + & + & - & - & + \\
\hline
\end{tabular}

Note: Presence (+) or absence (-)

No antioxidant activity was found in any of the extracts, by DPPH or $\mathrm{Fe}^{3+}$-phenanthroline. Similarly, none of the treatments by $A$. donax extracts reduced the number of larvae of the crustacean Artemia salina in the cytotoxicity test. Inhibitory effect on proliferation of microorganisms was slight in the antimicrobial assay, being observed only in the methanolic extract of rhizomes in two of the thirteen subjects tested. While some microorganisms did not react to the treatment, the most expressive result was the stimulus to proliferation, observed in several cultures (Table 4).

Table 4. Antimicrobial test results with thirteen different microorganisms treated with aqueous and methanolic extracts of leaves and rhizomes of Arundo donax

\begin{tabular}{|l|c|c|c|c|}
\hline \multirow{2}{*}{ Microorganism } & \multicolumn{2}{c|}{ Aqueous } & \multicolumn{2}{c|}{ Methanolic } \\
\cline { 2 - 5 } & Leaves & Rhizome & Leaves & Rhizome \\
\hline Acinetobacter baumannii & 0 & 0 & + & 0 \\
\hline Aeromonas hydrophila & 0 & 0 & + & 0 \\
\hline Candida albicans & 0 & 0 & + & 0 \\
\hline Citrobacter freundii & + & + & + & 0 \\
\hline Edwardsiella tarda & 0 & + & + & 0 \\
\hline Enterobacter cloacae & 0 & 0 & + & 0 \\
\hline Eschericia coli & + & 0 & + & - \\
\hline Klebsiella pneumoniae & + & 0 & + & - \\
\hline Morganella morganii & 0 & 0 & + & 0 \\
\hline Pseudomonas aeruginosa & + & 0 & + & 0 \\
\hline Salmonella enterica & 0 & + & + & 0 \\
\hline Serratia marcescens & + & 0 & + & 0 \\
\hline Staphylococcus aureus & 0 & 0 & + & 0 \\
\hline
\end{tabular}

Note: (-) indicates inhibitory effect, (+) indicates stimulatory effect, and (0) indicates that there was no effect

The nuclear magnetic resonance spectra showed a large number of signals in the chemical shift range between 3 and 5 ppm, a region characterized by the presence of sugars, in all analyzed extracts (Figure 3). In all extracts, it can be found the presence of aromatic hydrogen of glucose in alpha position (around $5.2 \mathrm{ppm}$ and with $\mathrm{J}=3.8 \mathrm{~Hz}$ ). Between 6 and $8 \mathrm{ppm}$, in all extracts, we can observe signals related to aromatic substances, but in less amount in the aqueous extract of rhizomes (Figure 3). The presence of signals in the aromatic region confirms the results of the TLC analysis that indicated the presence of flavonoids. The high concentration of sugars in all extracts, and especially in the methanol ones, suggest that they are probably linked to sugars (flavonoid glucosides). The presence of terpenes is also confirmed by several signals between 0.5 and $1.4 \mathrm{ppm}$ (Figure 3) in all extracts, characteristic of methyl groups of this class. But is still soon to confirm if they are triterpenes or other terpene classes. Small signals in the range of $11 \mathrm{ppm}$ are discernible in the ${ }^{1} \mathrm{H}$-NMR spectra of methanolic extracts from leaves and rhizomes (Figure 4). These are related to indolic alkaloid that was previously isolated from $A$. donax (Khuzhaev et al., 2004), and expected to occur between 10 and $11 \mathrm{ppm}$. 


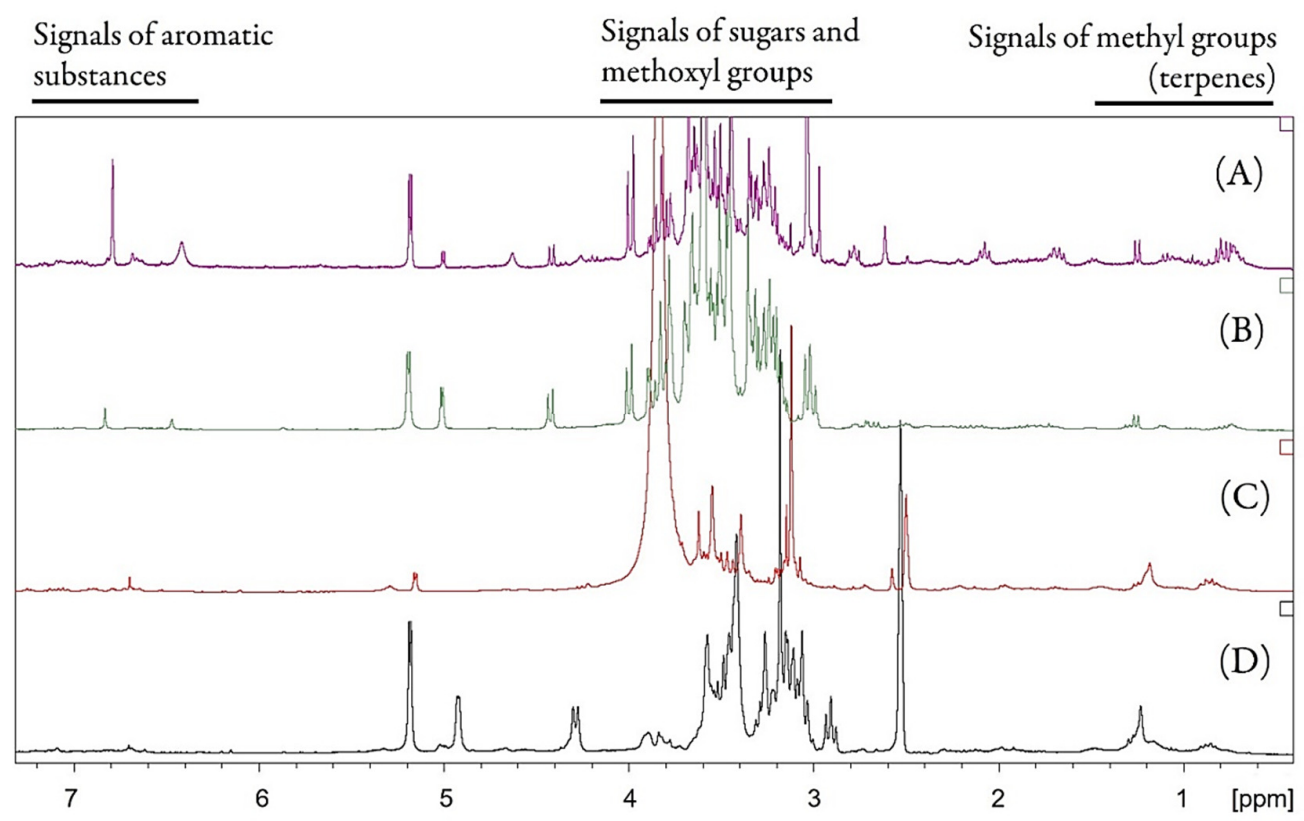

Figure 3. Nuclear magnetic expansion spectra of the region between 1 and $7 \mathrm{ppm}$ of the four different crude Arundo donax extracts: A) aqueous leaf $\left.\left(\mathrm{D}_{2} \mathrm{O}\right), \mathrm{B}\right)$ aqueous rhizome $\left.\left(\mathrm{D}_{2} \mathrm{O}\right), \mathrm{C}\right)$ methanolic leaf $\left(\mathrm{DMSO}-d_{6}\right)$ and D) methanolic rhizome (DMSO- $\left.d_{6}\right)(300 \mathrm{MHz})$

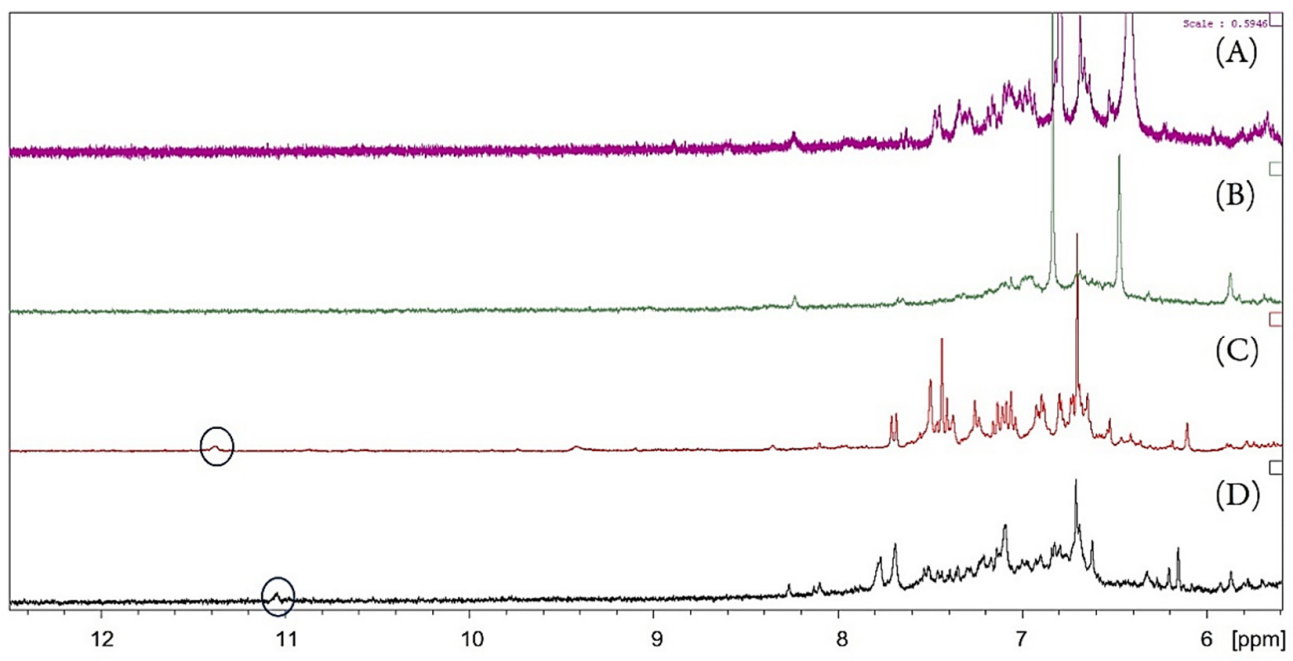

Figure 4. Nuclear magnetic resonance expansion spectra of the region between 6 and $12 \mathrm{ppm}$ of the four different crude Arundo donax extracts: a) aqueous leaf $\left.\left(\mathrm{D}_{2} \mathrm{O}\right), \mathrm{b}\right)$ aqueous rhizome $\left(\mathrm{D}_{2} \mathrm{O}\right)$, c) methanolic leaf $\left(\mathrm{DMSO}-d_{6}\right)$ and d) methanolic rhizome (DMSO- $\left.d_{6}\right)(300 \mathrm{MHz})$

\section{Discussion}

Arundo donax is a large perennial invasive grass that established and rapidly propagated in Cerrado areas of Central Brazil in the last decade (Simões et al., 2013; IABIN, 2019). The lateral propagation of the plant, which occurs through the growth and regrowth of the rhizome and fragments of the stem, gives rise to clonal populations that form large monospecific stands (Simões et al., 2013). 
We provide evidence that its invasive success can be attributed, in part, to the production of allelopathic compounds that could potentially inhibit seedling establishment of native species. Our results show that aqueous extracts of leaves and rhizomes of $A$. donax have an allelopathic effect on Cerrado woody species impairing germination and seedling growth. This has implications for the eradication of invasive stands of this species, especially when applying mechanical or chemical methods.

The rhizome is the main structure of propagation of the species and remains buried in the soil after cutting the aerial part, which is the main method used for controlling the spread of this species (Boose and Holt, 1999; Simões et al., 2013). Effective control of this plant is managed through complete removal of the rhizome (Bell, 1997), which is laborious, involves high costs, and is often not done. Applied weed control methods relying on cutting the plant back to soil level will probably result in plant resprouting and, particularly if the plant material is not removed, might also contribute to the release of allelochemicals into the soil in a continuous and lasting way, potentially inhibiting seed germination and establishment of other species.

The fragmentation of Cerrado environments, transforming the natural vegetation into patches surrounded by pastures and crop cultures facilitates the spread of different invader grasses. Leaf aqueous extracts of $A$. donax negatively affected germination and seedling growth of the invasive grass Megathyrsus maximus, which is widely distributed in the ecosystems of Cerrado (Filgueiras, 2015). Some authors attribute the success of the colonization of $M$. maximus to its rapid germination and seedling establishment, which increases its competitiveness relative to other species (Ferreira et al., 2008), than to its allelopathic potential which is low (Hartmann et al., 2017). We are not aware of studies addressing competitive interactions between $A$. donax and other invasive species and whether allelochemicals are involved. Although our results are not conclusive and require additional studies, allelopathy may enhance the competitive success of $A$. donax not only against native species but also against other invasive species.

TLC analysis showed that the molecules identified in the methanolic extracts belonged to the classes of alkaloids, flavonoids, and other phenolics, and are produced mostly in the leaves, which corroborates what was observed by other authors regarding the allelopathic efficiency of the extracts obtained from this organ (Hong et al., 2010; Temiz et al., 2013; Ahrar et al., 2017). In contrast, TLC analysis did not detect flavonoids and any other phenolic compounds in the rhizomes. Terpenes, which were also present in the leaves, were the main secondary metabolites in the crude aqueous and methanolic extracts of $A$. donax rhizomes. The presence of terpenes in rhizomes has been reported in other plants, e.g. species in the Zingiberaceae family (Afzal et al., 2013). By TLC we detected alkaloids only in the methanolic extract of leaves, despite a report of the presence of alkaloids in leaves, roots, and rhizomes of this species collected in Asia (Khuzhaev et al., 1994; 2004). However, we detected the presence of signs of indole alkaloids in both methanolic extracts (from rhizomes and leaves) by ${ }^{1} \mathrm{H}-\mathrm{NMR}$ analysis. It was possible to obtain indications of the presence of alkaloids in the signals with chemical shift in the range of 10-11 ppm in a spectrum of ${ }^{1} \mathrm{H}$, as found by other authors (Dijkstra et al., 1989; Dijkstra et al., 1990).

The absence of antioxidant activity in the analyzed extracts is a result similar to that observed by other authors (Menezes et al., 2004). However, molecules that have antioxidant activity when in isolated state or in fractions of extracts may not be active when diluted in crude extracts, such as those used in this study. Thus, the results found in the tests performed are not conclusive on the presence of molecules with antioxidant properties in $A$. donax.

Arundo donax is a species often found in humid habitats such as the shores of rivers and lakes. Active compounds present in the rhizomes and shoot fragments can be washed into the water bodies and interfere through the liquid medium in other plant species and microorganisms (Gopal and Goel, 1993). However, the test with Artemia salina showed that the aqueous extract of $A$. donax, in the analyzed concentrations, had low or no toxicity. This microcrustacean is a good preliminary indicator of the cytotoxicity of the material (Lhullier et al., 2006). The analysis is based on the median lethal concentration, or $\mathrm{LC}_{50}$, the concentration in $\mu \mathrm{g} / \mathrm{mL}$ that causes the death of half of the organisms tested. To confirm the cytotoxicity of the sample in the test of $A$. salina the $\mathrm{LC}_{50}$ should be equal to or less than $30 \mu \mathrm{g} / \mathrm{mL}$ (Meyer et al., 1982). This value was not achieved by 
any of the extracts. The results may indicate that $A$. donaxdoes not have biological activity on the aquatic fauna and that it has negative effects only on other plants, or that the concentrations analyzed were low to cause toxicity.

In the results of the antimicrobial activity, only the methanolic extracts of the rhizome showed inhibitory effects on some microorganisms, Klebsiella pneumoniae and Morganella morganii. There was no significant variation in the growth of microorganisms in most treatments. The stimulus to the growth of some microorganisms especially in the methanolic extract of leaves possibly occurred due to the high carbohydrate content, observed in the chromatographic test with Anisaldehyde and in the ${ }^{1} \mathrm{H}-\mathrm{NMR}$ analyses.

\section{Conclusions}

We were able to show that clonal populations of $A$. donax that were successfully established in Cerrado ecosystems conserved the ability to produce a variety of secondary metabolites. We also provide evidence that the aqueous extracts of leaves and rhizomes were detrimental to germination and seedling development of several Cerrado tree species and an invasive African grass, Megathyrsus maximus. Leaf extracts were more effective than rhizome extracts. This information is important not only for better understanding the invasive potential of the species and for developing measurements for its effective control, but also for bioprospecting studies to isolate bioactive compounds in this species.

\section{Authors' Contributions}

LG, CSF, and SCCO conceived and designed the study. LG performed the experiments and collected the data (with assistance of CVN, MCSS, MTFE). CSF, ACF, LG, and CVN analyzed and interpreted the data. CSF, ACF, LG wrote the first draft. All authors discussed the results and contributed comments to the manuscript. All authors read and approved the final manuscript.

\section{Acknowledgements}

This work was supported by Fundação de Apoio à Pesquisa do Distrito Federal (FAPDF, grant numbers 193.000.195/2014; 00193.00000922/2019-89), Conselho Nacional de Desenvolvimento Científico e Tecnológico (CNPq, grant numbers 311362/2019-2, 405804/2013-0, 305177/2019-2), Coordenação de Aperfeiçoamento de Pessoal de Nível Superior (CAPES, grant number 23038.000738/2013-78) and Fundação de Amparo à Pesquisa do Estado do Amazonas (FAPEAM). L.G.L.S. received a Scholarship from CAPES, Brazil (grant number 0001).

\section{Conflict of Interests}

The authors declare that there are no conflicts of interest related to this article.

\section{References}

Abu-Romman S, Ammari TG (2015). Allelopathic effect of Arundo donax, a Mediterranean invasive grass. Plant Omics Journal 8:287-291. 
Afzal A, Oriqat G, Khan MA, Jose J, Afzal M (2013). Chemistry and biochemistry of terpenoids from curcuma and related species. Journal of Biologically Active Products from Nature 3(1):1-55. https://doi.org/10.1080/22311866.2013.782757

Ahrar M, Doneva D, Tattini M, Brunetti C, Gori A, Rodeghiero M, ... Velikova V (2017). Phenotypic differences determine drought stress responses in ecotypes of Arundo donax adapted to different environments. Journal of Experimental Botany 68:2439-2451. https://doi.org/10.1093/jxb/erx125

Al-Snafi AE (2015). The constituents and biological effects of Arundo donax - a Review. International Journal of Pharmaceutical and Phytopharmacological Research 6:34-40.

Bell GP (1997). Ecology and management of Arundo donax, and approaches to riparian habitat restoration in southern California. Plant Invasions: Studies from North America and Europe. Leiden, Netherlands: Backhuys Publishers.

Boose A, Holt J (1999). Environmental effects on asexual reproduction in Arundo donax. Weed Research 39:117-127. https://doi.org/10.1046/j.1365-3180.1999.00129.x

Calina D, Olah N, Patru M, Docea A, Popescu H, Bubulica M (2013). Chromatografic analysis of the flavonoids from Robinia pseudoacacia species. Current Health Sciences Journal 39(4):232-236.

Coffman GC, Ambrose RF, Rundel PW (2010). Wildfire promotes dominance of invasive giant reed (Arundo donax) in riparian ecosystems. Biological Invasions 12:2723-2734. https://doi.org/10.1007/s10530-009-9677-Z

Corno L, Pilu R, Adani F (2014). Arundo donax L.: A non-food crop for bioenergy and bio-compound production. Euphytica 196:169-181. https://doi:10.1016/j.biotechadv.2014.10.006

Dijkstra GDH, Kellog RM, Wynberg H, Svendsen JS, Marko I, Sharpless KB (1989). Conformational study of cinchona alkaloids. A combined NMR, molecular mechanics and x-ray approach. Journal of the American Chemical Society 111:8070-8076. https://doi.org/10.1021/ja00203a001

Dijkstra GDH, Kellog RM, Wynberg H (1990). Conformational study of cinchona alkaloids. A combined NMR and molecular orbital approach. Journal of Organic Chemistry 55:6121-6131. https://doi.org/10.1021/jo00312a017

Favaretto A, Scheffer-Basso SM, Perez NB (2018). Allelopathy in Poaceae species present in Brazil. A review. Agronomy for Sustainable Development 38:22. https://doi.org/10.1007/s13593-018-0495-5

Ferreira NR, de Medeiros RB, Soares GL (2008). Potencial alelopático do capim-annoni-2 (Eragrostis plana Nees) na germinação de sementes de gramíneas perenes estivais [Alelopathic potential of capim-annoni-2 (Eragrostis plana Nees) on the seed germination of summer perennial grasses]. Revista Brasilera de Sementes 30:43-50. https://doi.org/10.1590/S0101-31222008000200006

Filgueiras TS (2015). Megathyrsus in Lista de Espécies da Flora do Brasil [List of Species of the Brazilian Flora]. Botanical Garden of Rio de Janeiro. http://floradobrasil.jbrj.gov.br/jabot/floradobrasil/FB86869

Fujii Y (2003). Allelopathy in the natural and agricultural ecosystems and isolation of potent allelochemicals from Velvet bean (Mucuna pruriens) and hairy vetch (Vicia villosa). Biological Sciences in Space 17:6-13. https://doi.org/10.2187/bss.17.6

Gomes L, Miranda HS, Soares-Filho B, Rodrigues L, Oliveira U, Bustamante MMC (2020) Responses of plant biomass in the Brazilian Savanna to frequent fires. Frontiers in Forests and Global Change 3:507710. https://doi.org/10.3389/ffgc.2020.507710

Gopal B, Goel U (1993). Competition and allelopathy in aquatic plant communities. The Botanical Review 59:155-210. https://doi.org/10.1007/BF02856599

Hartmann KCD, Fortes AMT, Cassol FDR, Valmorbida R, de Mendonça LC (2017). Atividade alelopática de espécies invasoras sobre a germinação e o desenvolvimento inicial de arbórea nativa [Allelopathic activity of invasive species on the germination and initial development of native tree]. Floresta 47:229-235. https://doi.org/10.5380/rf.v47i3.50222

Hierro JL, Callaway RM (2003). Allelopathy and exotic plant invasion. Plant and Soil 256:29-39. https://doi.org/10.1023/A:1026208327014

Hong Y, Hu H, Sakoda A, Sagehashi M (2010). Isolation and characterization of antialgal allelochemicals from Arundo donax L. Allelopathy Journal 25:357-368.

IABIN (2019). IABIN, Invasive Information Network (13N). Inter-American Biodiversity Information Network. http://www.institutohorus.org.br/iabin/i3n/index.html

Jork H, Funk W, Fischer W, Wimmer H (1990). Thin-layer chromatography, reagents and detection methods. Weinheira, Germany: Wiley-VCH. https://doi.org/10.1016/S0003-2670(00)83962-8 
Khuzhaev VU, Aripova SF, Shakirov RSh (1994). Dynamics of the accumulation of the alkaloids of Arundo donax. Chemistry of Natural Compounds 30:637-638.

Khuzhaev VU, Zhalolov IZh, Levkovich MG, Aripova SF, Shashkov AS (2004). Alkaloids of Arundo donax L. 15.* A new dimeric indole alkaloid arundarine from the roots of Arundo donax L. Russian Chemical Bulletin 53:765-1767. https://doi.org/10.1007/s11172-005-0033-X

Lhullier C, Horta P, Falkenberg M (2006). Avaliação de Extratos de Macroalgas Bênticas do Litoral Catarinense Utilizando Teste de Letalidade para Artemia salina [Evaluation of macroalgae from Santa Catarina's coast with the brine shrimp assay]. Revista Brasileira de Farmacognosia 16:158-163. https://doi.org/10.1590/S0102$695 \times 2006000200005$

Maceda-Veiga A, Basas H, Lanzaco G, Sala M, de Sostoa A, Serra A (2016). Impacts of the invader giant reed (Arundo donax) on riparian habitats and ground arthropod communities. Biological Invasions 18:731-749. https://doi.org/10.1007/s10530-015-1044-7

Mahmoodzadeh H, Mahmoodzadeh M (2014). Allelopathic effects of rhizome aqueous extract of Cynodon dactylon L. on seed germination and seedling growth of legumes. Labiatae and Poaceae. Iranian Journal of Plant Physiology 4:1047-1054. https://doi.org/10.22034/IJPP.2014.540648

Mariani C, Cabrini R, Danin A, Piffanelli P, Fricano A, Gomarasca S, Dicandilo M, Grassi F, Soave C (2010). Origin, diffusion and reproduction of the giant reed (Arundo Donax L.): a promising weedy energy crop. Annals of Applied Biology 157:191-202. https://doi.org/10.1111/j.1744-7348.2010.00419.X

Martins D, Fachin-Espinar MT, de Oliveira TA, Lima KCS, Cavalcanti R, Teles BR, Nunez CV (2014). Phytochemical prospection and biological activity of Duroia macrophylla (Rubiaceae). Journal of Pharmacy \& Pharmacognosy Research 2:158-171. https://doi.org/10.1155/2013/605831

Menezes PR, Schwartz EA, Santos CA (2004). In vitro antioxidant activity of species collected in Paraná. Fitoterapia 75:398-400. https://doi.org/10.1016/j.fitote.2004.01.014

Meyer BN, Ferrigni NR, Putnam JE, Jacobsen LB, Nichols DE, McLaughlin JL (1982). Brine shrimp: a convenient general bioassay for active plant constituents. Planta Medica 45:31-34. https://doi.org/10.1055/s-2007-971236

Myers N, Mittermeier RA, Mittermeier CG, Da Fonseca GAB, Kent J (2000). Biodiversity hotspots for conservation priorities. Nature 403:853-858. https://doi.org/10.1038/35002501

Możdżeń K, Barabasz-Krasny B, Zandi P, Kliszcz A, Puła J (2020). Effect of aqueous extracts from Solidago canadensis L. leaves on germination and early growth stages of three cultivars of Raphanus sativus L. var. radicula Pers. Plants 9(11):1549. https://doi.org/10.3390/plants9111549

Pascual ME, Carretero ME, Slowing KV, Villar A (2002). Simplified screening by TLC of plant drugs. Pharmaceutical Biology 40:139-143. https://doi.org/10.1076/phbi.40.2.139.5849

Peres JCF, de Carvalho LR, Gonçalez E, Berian LOS, Felicio JD (2012). Evaluation of antifungal activity of seaweed extracts. Ciência e Agrotecnologia 36:294-299. https://doi.org/10.1590/S1413-70542012000300004

Simões KCC, Hay JDV, de Andrade CO, Júnior OAC, Gomes RAT (2013). Distribuição de Cana-do-Reino (Arundo donax L.) no Distrito Federal, Brasil [Distribution of Cane-do-Reino (Arundo donax L.) in the Federal District, Brazil]. Biodiversidade Brasileira 3:97-105.

Temiz A, Akbas S, Panov D, Terziev N, Alma MH, Parlak S, Kose G (2013). Chemical composition and efficiency of biooil obtained from giant cane (Arundo donax L.) as a wood preservative. BioResources 8:2084-2098. https://doi.org/10.15376/biores.8.2.2084-2098
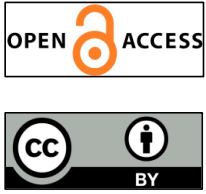

The journal offers free, immediate, and unrestricted access to peer-reviewed research and scholarly work. Users are allowed to read, download, copy, distribute, print, search, or link to the full texts of the articles, or use them for any other lawful purpose, without asking prior permission from the publisher or the author.

License - Articles published in Notulae Botanicae Horti Agrobotanici Cluj-Napoca are Open-Access, distributed under the terms and conditions of the Creative Commons Attribution (CC BY 4.0) License.

(c) Articles by the authors; UASVM, Cluj-Napoca, Romania. The journal allows the author(s) to hold the copyright/to retain publishing rights without restriction. 
Supplementary Table S1. The effect of different concentrations of aqueous extracts (\%) from leaves and rhizomes of Arundo donax on the length $(\mathrm{cm})$ of shoots and roots of seedlings of the invasive African grass Megathyrsus maximus and five native Cerrado tree species

\begin{tabular}{|c|c|c|c|c|c|c|c|c|c|c|c|c|}
\hline \multirow[t]{2}{*}{ Treatment } & \multicolumn{2}{|c|}{$\begin{array}{l}\text { Handroanthus } \\
\text { impetiginosus }\end{array}$} & \multicolumn{2}{|c|}{$\begin{array}{l}\text { Megathyrsus } \\
\text { maximus }\end{array}$} & \multicolumn{2}{|c|}{$\begin{array}{l}\text { Eriotheca } \\
\text { pubescens }\end{array}$} & \multicolumn{2}{|c|}{$\begin{array}{c}\text { Pseudobombax } \\
\text { tomentosum }\end{array}$} & \multicolumn{2}{|c|}{$\begin{array}{l}\text { Guazuma } \\
\text { ulmifolia }\end{array}$} & \multicolumn{2}{|c|}{$\begin{array}{c}\text { Parkia } \\
\text { platycephala }\end{array}$} \\
\hline & Shoot & Root & Shoot & Root & Shoot & Root & Shoot & Root & Shoot & Root & Shoot & Root \\
\hline \multicolumn{13}{|c|}{ Leaf extract } \\
\hline Control & $\begin{array}{l}1.45 \pm \\
0.12 \mathrm{a}\end{array}$ & $\begin{array}{r}2.64 \pm \\
0.17 \mathrm{a}\end{array}$ & $\begin{array}{l}1.53 \pm \\
0.10 \mathrm{ab}\end{array}$ & $\begin{array}{l}2.76 \pm \\
0.19 \mathrm{a}\end{array}$ & $\begin{array}{l}1.89 \pm \\
0.12 \mathrm{a}\end{array}$ & $\begin{array}{l}4.02 \pm \\
0.32 \mathrm{a}\end{array}$ & $\begin{array}{l}0.83 \pm \\
0.06 \mathrm{a}\end{array}$ & $\begin{array}{l}1.03 \pm \\
0.09 \mathrm{a}\end{array}$ & $\begin{array}{l}1.17 \pm \\
0.08 \mathrm{a}\end{array}$ & $\begin{array}{l}1.98 \pm \\
0.17 \mathrm{a}\end{array}$ & $\begin{array}{l}2.02 \pm \\
0.19 \mathrm{ab}\end{array}$ & $\begin{array}{l}1.52 \pm \\
0.07 \mathrm{a}\end{array}$ \\
\hline $1.25 \%$ & $\begin{array}{l}1.09 \pm \\
0.11 \mathrm{ab}\end{array}$ & $\begin{array}{l}2.39 \pm \\
0.20 \mathrm{a}\end{array}$ & $\begin{array}{l}1.78 \pm \\
0.25 \mathrm{a}\end{array}$ & $\begin{array}{l}2.21 \pm \\
0.39 \mathrm{ab}\end{array}$ & $\begin{array}{c}0.00 \pm \\
0 \mathrm{~b}\end{array}$ & $\begin{array}{l}0.87 \pm \\
0.22 b\end{array}$ & $\begin{array}{l}1.06 \pm \\
0.09 \mathrm{a}\end{array}$ & $\begin{array}{l}1.04 \pm \\
0.14 \mathrm{a}\end{array}$ & $\begin{array}{l}1.22 \pm \\
0.05 \mathrm{a}\end{array}$ & $\begin{array}{l}1.53 \pm \\
0.12 \mathrm{a}\end{array}$ & $\begin{array}{r}2.29 \pm \\
0.20 \mathrm{a}\end{array}$ & $\begin{array}{l}1.73 \pm \\
0.06 \mathrm{a}\end{array}$ \\
\hline $2.50 \%$ & $\begin{array}{l}1.24 \pm \\
0.11 \mathrm{ab}\end{array}$ & $\begin{array}{l}2.45 \pm \\
0.17 \mathrm{a}\end{array}$ & $\begin{array}{l}0.90 \pm \\
0.21 \mathrm{bc}\end{array}$ & $\begin{array}{l}1.13 \pm \\
0.30 \mathrm{bc}\end{array}$ & $\begin{array}{l}0.09 \pm \\
0.05 b\end{array}$ & $\begin{array}{l}0.39 \pm \\
0.10 b\end{array}$ & $\begin{array}{l}0.46 \pm \\
0.02 b\end{array}$ & $\begin{array}{l}0.61 \pm \\
0.05 b\end{array}$ & $\begin{array}{l}0.83 \pm \\
0.09 \mathrm{ab}\end{array}$ & $\begin{array}{l}1.06 \pm \\
0.12 \mathrm{~b}\end{array}$ & $\begin{array}{l}1.28 \pm \\
0.17 \mathrm{~b}\end{array}$ & $\begin{array}{l}1.09 \pm \\
0.11 \mathrm{~b}\end{array}$ \\
\hline $5 \%$ & $\begin{array}{l}1.18 \pm \\
0.11 \mathrm{ab}\end{array}$ & $\begin{array}{l}2.16 \pm \\
0.18 \mathrm{a}\end{array}$ & $\begin{array}{c}1.03 \pm \\
0.42 \\
\mathrm{abc}\end{array}$ & $\begin{array}{r}0.62 \pm \\
0.25 \mathrm{c}\end{array}$ & $\begin{array}{l}0.66 \pm \\
0.20 b\end{array}$ & $\begin{array}{l}1.25 \pm \\
0.21 \mathrm{~b}\end{array}$ & $\begin{array}{l}0.45 \pm \\
0.03 b\end{array}$ & $\begin{array}{l}0.58 \pm \\
0.04 \mathrm{~b}\end{array}$ & $\begin{array}{l}0.75 \pm \\
0.23 \mathrm{~b}\end{array}$ & $\begin{array}{l}1.35 \pm \\
0.54 \mathrm{~b}\end{array}$ & $\begin{array}{l}1.22 \pm \\
0.38 \mathrm{bc}\end{array}$ & $\begin{array}{l}0.92 \pm \\
0.24 b\end{array}$ \\
\hline $10 \%$ & $\begin{array}{l}0.86 \pm \\
0.09 \mathrm{~b}\end{array}$ & $\begin{array}{l}1.39 \pm \\
0.12 \mathrm{~b}\end{array}$ & $\begin{array}{c}0.00 \pm \\
0 c\end{array}$ & $\begin{array}{c}0.00 \pm \\
0 c\end{array}$ & $\begin{array}{c}0.00 \pm \\
0 \mathrm{~b}\end{array}$ & $\begin{array}{l}0.36 \pm \\
0.15 b\end{array}$ & $\begin{array}{c}0.00 \pm \\
0 c\end{array}$ & $\begin{array}{c}0.00 \pm \\
0 c\end{array}$ & $\begin{array}{c}0.00 \pm \\
0 c\end{array}$ & $\begin{array}{c}0.00 \pm \\
0 \mathrm{c}\end{array}$ & $\begin{array}{c}0.00 \pm \\
0 c\end{array}$ & $\begin{array}{c}0.00 \pm \\
0 c\end{array}$ \\
\hline \multicolumn{13}{|c|}{ Rhizome extract } \\
\hline Control & $\begin{array}{l}1.20 \pm \\
0.13 \mathrm{a}\end{array}$ & $\begin{array}{l}2.66 \pm \\
0.23 \mathrm{a}\end{array}$ & $\begin{array}{l}1.53 \pm \\
0.10 \mathrm{a}\end{array}$ & $\begin{array}{l}2.76 \pm \\
0.19 \mathrm{ab}\end{array}$ & $\begin{array}{l}1.89 \pm \\
0.12 \mathrm{a}\end{array}$ & $\begin{array}{l}4.02 \pm \\
0.32 \mathrm{a}\end{array}$ & $\begin{array}{l}0.83 \pm \\
0.06 \mathrm{a}\end{array}$ & $\begin{array}{l}1.03 \pm \\
0.09 \mathrm{ab}\end{array}$ & $\begin{array}{l}1.17 \pm \\
0.08 \mathrm{ab}\end{array}$ & $\begin{array}{l}1.98 \pm \\
0.17 \mathrm{a}\end{array}$ & $\begin{array}{l}2.02 \pm \\
0.19 \mathrm{a}\end{array}$ & $\begin{array}{l}1.52 \pm \\
0.07 \mathrm{a}\end{array}$ \\
\hline $1.25 \%$ & $\begin{array}{l}0.28 \pm \\
0.09 \mathrm{~b}\end{array}$ & $\begin{array}{l}1.37 \pm \\
0.14 \mathrm{~b}\end{array}$ & $\begin{array}{l}1.30 \pm \\
0.29 \mathrm{a}\end{array}$ & $\begin{array}{r}2.21 \pm \\
0.48 \mathrm{a}\end{array}$ & $\begin{array}{l}1.27 \pm \\
0.07 \mathrm{~b}\end{array}$ & $\begin{array}{l}2.43 \pm \\
0.16 \mathrm{~b}\end{array}$ & $\begin{array}{l}1.39 \pm \\
0.14 \mathrm{~b}\end{array}$ & $\begin{array}{l}1.37 \pm \\
0.13 \mathrm{bc}\end{array}$ & $\begin{array}{l}1.51 \pm \\
0.09 \mathrm{bc}\end{array}$ & $\begin{array}{r}2.10 \pm \\
0.15 \mathrm{a}\end{array}$ & $\begin{array}{c}1.28 \pm \\
0.06 \mathrm{bc}\end{array}$ & $\begin{array}{l}1.65 \pm \\
0.15 \mathrm{a}\end{array}$ \\
\hline $2.50 \%$ & $\begin{array}{l}1.39 \pm \\
0.23 \mathrm{a}\end{array}$ & $\begin{array}{l}2.37 \pm \\
0.36 \mathrm{ab}\end{array}$ & $\begin{array}{l}1.62 \pm \\
0.33 \mathrm{a}\end{array}$ & $\begin{array}{l}2.96 \pm \\
0.59 \mathrm{ab}\end{array}$ & $\begin{array}{l}1.10 \pm \\
0.06 \mathrm{bc}\end{array}$ & $\begin{array}{l}2.42 \pm \\
0.16 \mathrm{~b}\end{array}$ & $\begin{array}{l}1.30 \pm \\
0.09 \mathrm{~b}\end{array}$ & $\begin{array}{l}1.47 \pm \\
0.11 \mathrm{c}\end{array}$ & $\begin{array}{l}1.02 \pm \\
0.06 \mathrm{a}\end{array}$ & $\begin{array}{l}1.53 \pm \\
0.19 \mathrm{~b}\end{array}$ & $\begin{array}{l}1.09 \pm \\
0.05 \mathrm{c}\end{array}$ & $\begin{array}{l}1.54 \pm \\
0.14 \mathrm{a}\end{array}$ \\
\hline $5 \%$ & $\begin{array}{l}1.24 \pm \\
0.15 \mathrm{a}\end{array}$ & $\begin{array}{c}2.25 \pm \\
0.24 \mathrm{ab}\end{array}$ & $\begin{array}{l}1.82 \pm \\
0.27 \mathrm{ab}\end{array}$ & $\begin{array}{l}2.84 \pm \\
0.43 \mathrm{ab}\end{array}$ & $\begin{array}{c}1.00 \pm \\
0.10 \mathrm{bc}\end{array}$ & $\begin{array}{l}1.62 \pm \\
0.20 \mathrm{c}\end{array}$ & $\begin{array}{c}0.71 \pm \\
0.08 \mathrm{a}\end{array}$ & $\begin{array}{l}0.82 \pm \\
0.09 \mathrm{a}\end{array}$ & $\begin{array}{l}1.55 \pm \\
0.10 c\end{array}$ & $\begin{array}{c}1.80 \pm \\
0.16 \\
\mathrm{ab}\end{array}$ & $\begin{array}{l}1.62 \pm \\
0.08 \mathrm{ab}\end{array}$ & $\begin{array}{l}1.83 \pm \\
0.17 \mathrm{a}\end{array}$ \\
\hline $10 \%$ & $\begin{array}{c}0.95 \pm \\
0.14 \mathrm{ab}\end{array}$ & $\begin{array}{c}1.82 \pm \\
0.28 \mathrm{ab}\end{array}$ & $\begin{array}{l}2.24 \pm \\
0.18 \mathrm{~b}\end{array}$ & $\begin{array}{l}3.37 \pm \\
0.38 \mathrm{~b}\end{array}$ & $\begin{array}{r}0.92 \pm \\
0.07 c\end{array}$ & $\begin{array}{l}1.96 \pm \\
0.16 \mathrm{c}\end{array}$ & $\begin{array}{c}0.00 \pm \\
0 \mathrm{c}\end{array}$ & $\begin{array}{c}0.00 \pm \\
0 \mathrm{~d}\end{array}$ & $\begin{array}{c}1.30 \pm \\
0.12 \mathrm{abc}\end{array}$ & $\begin{array}{c}1.69 \pm \\
0.24 \\
\mathrm{ab}\end{array}$ & $\begin{array}{c}1.10 \pm \\
0.08 b c\end{array}$ & $\begin{array}{l}1.59 \pm \\
0.25 \mathrm{a}\end{array}$ \\
\hline
\end{tabular}

Mean \pm standard error. Different letters denote significant differences at $\mathrm{p}<0.05$ between concentration levels.

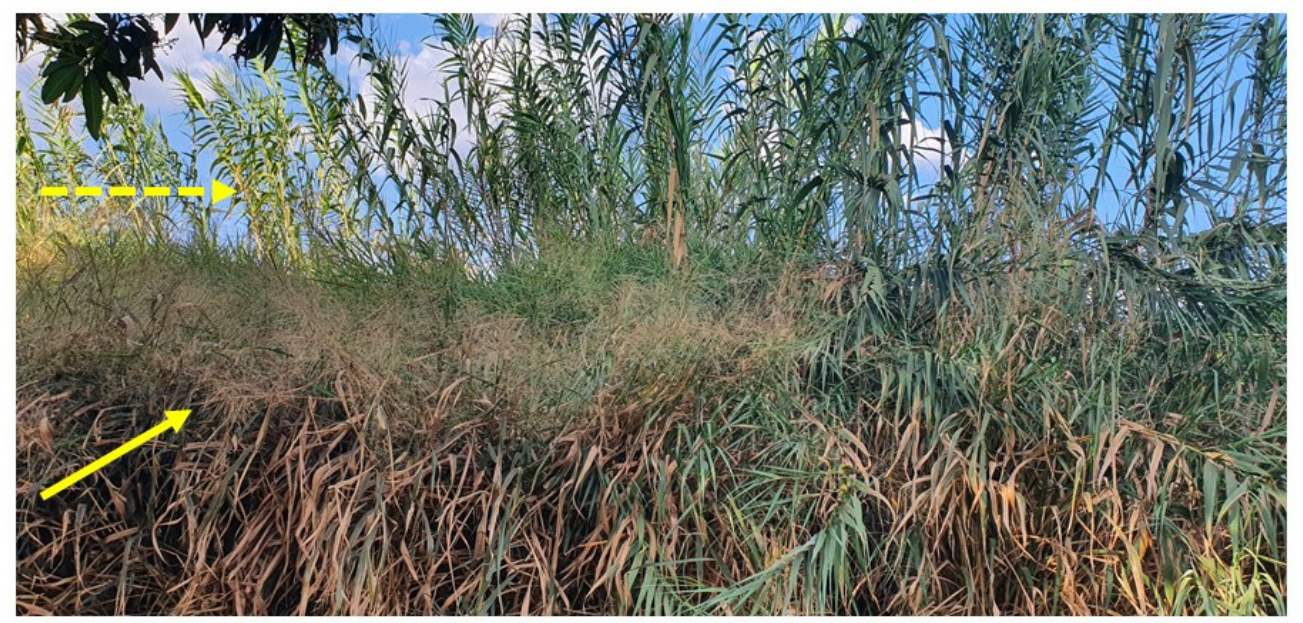

Figure S1. Megathyrsus maximus (linear arrow) co-occurring with Arundo donax (dashed arrow) in degraded Cerrado in Brasilia, Federal District, Brazil 